\title{
An Anthropologico-Metaphysical Reflection on the Being of Man: A Philosophical Enquiry
}

\section{Ignatius Nnaemeka Onwuatuegwu}

Department of Philosophy, Faculty of Arts, Nnamdi Azikiwe University, Awka, Nigeria

\section{Email address:}

in.onwuatuegwu@unizik.edu.ng,frig2014@gmail.com

\section{To cite this article:}

Ignatius Nnaemeka Onwuatuegwu. An Anthropologico-Metaphysical Reflection on the Being of Man: A Philosophical Enquiry. International Journal of Literature and Arts. Vol. 9, No. 3, 2021, pp. 143-146. doi: 10.11648/j.ijla.20210903.14

Received: April 29, 2021; Accepted: May 20, 2021; Published: May 31, 2021

\begin{abstract}
The contemporary man is gradually and systematically, though unknowingly becoming so mechanical and headstrongly wallowing deeply into the quagmire of a total oblivion of his own being. Consequently, the contemporary technolization and scientificalization of the present human society has necessarily estranged man from God and from his own very self. Invariably, life is becoming more mechanical and meaningless, and disjointedness of the contemporary man has equally affected his way of conceiving reality in general. It is this pitiable condition of man the present disjointed and fragmented society that has around the researcher's interest into reflecting on the anthropologico-metaphysical reflection on the being of man. Man as being is a profound mystery. As a mystery, man cannot be fully and comprehensively understood. The knowledge of man is over and above man himself, even though the knowledge of man is not against human comprehension nor does it destroy human reasoning. It is in the anthropological question of the being of man that the metaphysics of God emerged. For man to comprehensively understand his very being, he has first to become God, for it is God alone who knows man through and through. Even man's unformed flame is known by him. Hence, it is only in relation to God that man can meaningfully discover himself understand his own very being. It is this mystery of the being of man that the writer attempts to unravel in this work. The researcher primarily employed the philosophical method of critical reflection as a means to achieve this goal. Man as a created being, on the basis of metaphysical principle of finality, is driving on as well as sustained by its metaphysical and meta-psychical desire to see God.
\end{abstract}

Keywords: Man, Anthropological, Metaphysical, Soul, Body

\section{General Introduction}

The question of what man is reflects the personhood of man or the human- ness of man. The question is not as easy as it sounds. In order to answer this philosophical/anthropological question which is dimensionally both physical and metaphysical, there is the need for one to delve into the profundity of man himself. Knowledge of man cannot be said to be absolute with regard to man's interiority, since man is a self-transcendent animal. With this in mind, Buber says:

man's essential life is not to be grasped from what unrolls in the individual's inner life... but from the distinctiveness of his relation to things and living beings. [1]

It is in man's relation with the world/things, fellow men and implicitly with God would man be able to grasp what he essentially is.
Man is an animal of two worlds. In the being of man is a meeting point of the spiritual world and the sensible material world. He has both the qualities of a spirit and that of a body. Invariably, in the order of the spirit, man is the least of the spiritual beings. In the corporeal order, man is hierarchically the first and the greatest. Man's position is as a result of his rationality. Man is the only rational corporeal being. St. Thomas Aquinas recognizes this when he says that "man is man in virtue of his rationality". [2] Consequently, it is this rationality that endows man with the wisdom that enables him to raise the question about the world, God and himself.

Man is a composite being consisting of the soul and of the body (form and matter). [3] Form transcends the material world of things. Man's facticity and perspectivity, therefore, is as a result of his body. Facticity implies that because of my body, I am always conditioned. Again, because of my perspectivism, I cannot be looking up and looking down or 
forward at the same time. Hence, the body can be the starting point of Philosophy, but the body alone is neither the starting point of a person nor the soul the starting point. Rather, it is the en-gatheredness of the body and the soul which is made in the complicated and mysterious being called man.

However, unlike Plato, "body is not a prison into which the soul is held and in which the soul struggles in order to liberate itself". [4] On the contrary, and on a strong note, the body is not intrinsically evil. Man is neither a body nor a soul, but body and soul in unity. The two are the indispensable constituents of man. To have full knowledge of man, the two aspects of man must be put into consideration. Radical distinction of the soul and the body is a distortion and degradation of the nature of man which does not consist of the body or the soul in isolation. Each set apart cannot make a man but only in the union with the other. Aquinas, hence, insists that "It is rather the soul that contains the body and makes it one..." [5] Donceel in a total agreement with the above line of thought writes thus,

.. the body is not simply something different from the soul,

but the soul itself in its outer manifestation, in its worldly spatio-temporal givenness. [6]

Any attempt to separate the two (soul and body) becomes an attempt to make a cessation of man. The soul alone becomes a spirit and the body alone becomes a corpse and not a man.

\section{What Is Man}

The spiritual constituent of man is not amenable to scientific and technological study, neither can it be adequately accounted for by psychology and other humanist sciences. The knowledge of man then, becomes problematic. The knowledge of man, therefore, involves some other sciences beyond laboratory experiments and practical sciences. It was on this ground that Heidegger declared in his Kant and the problem of Metaphysics that:

No age has known so much and so many different things, about man as ours... And no age has known less than ours of what man is. [7]

In the book, Being and Time, Heidegger tries to give an account of the knowledge of man by the analysis of man's relation to his own being. However, he did this by estranging this relation from every other necessary human relations. He only succeeded in giving account of what the age of man is and not what man really is. Hence, the meaning of man remains problematic. This is due to the epistomologization of metaphysics and the de- metaphysicalization of anthropology of the modern era and contemporary era respectively.

The proper realization of the humanness of man is situated within the whole ultimate question of Being who God is himself. God is a being of intellection and he is absolutely free to do whatever he wills. Hence, this man, the most favoured creature of God and the apex of creation most resembles God in whose image and likeness he was created. Onwuatuegwu and Emekwulu captured the idea very well when they write that: "Man beyond being intelligent, is also free in his actions and deliberations in the face of serious and difficult decisions and choices" [8] Strictly speaking, the question of man emerged only in the context of Being whose act it is to be. Man is not a necessary being. He participates in the being of God who is his own being. The question of what man is, therefore, evokes God's question who is the source of all that exist. [9] To have full understanding of man, man should be traced back to his original cause. Aquinas, thus, opines:

... whatever is found in anything by participation must be caused in it by that to which it belongs essentially... therefore all beings apart from God are not their own being but are beings by participation. Therefore, it must be that things which are diversified by the diverse participation of their being... are caused by one first being who possess being most perfectly. [10]

Hence it is only anthropology which is both metaphysical and theocentric that is in the position to claim an adequate knowledge or understanding of man.

\section{The Profound Knowledge of Man Is in God}

Consequently, man is devoid of that wisdom which would have made it possible for him to grasp the full knowledge of himself, despite and in spite of all his technological skills and scientific knowledge. This is due to the Post-Kantian rejection of metaphysics. But if metaphysics is declared unnecessary, the question of God is already indirectly discarded equally. Buber contends that it is in God that man encounters himself fully as one reality. However, he holds that the knowledge of God on the other hand, is not necessarily outside man. Rather, man is a road to God.

Anthropology stems from metaphysics of being. It is when man begins to ask questions concerning beings and about his own being that he comes to the realization of the metaphysical depth of himself and then becomes problematic to himself. Capturing this, therefore, Onwuatuegwu maintains that man is not a being that is satisfied by merely being in the world. [11] Meanwhile, the science of anthropology emerges. Scheler identified distinctly the situation in our age from which anthropology started. Thus: We are the first epoch in which man has become fully and thoroughly 'problematic' to himself; in which he no longer knows what he essentially is, but at the same time also knows that he does not know. [12]

But if man does not know what he essentially is and at the same time knows that he does not know, therefore, the question of epistemology comes up. Admittedly, man is an epistemological being as well. Man does not only seek to know but also knows when he is lacking in this knowledge. It is the man's consciousness of his own ignorance that makes him move out of himself in a quest for knowledge.

Inherently, man is a self-trandcending animal. As a result of this, man becomes very difficult to comprehend even by himself, despite and in spite of the intensity of man's 
curiosity and enthusiasm to know. The anthropological as well as the philosophical stand for solving the question of what man is, therefore, demands research into the domain of God, who is the original cause of the very being of manbecause the profundity of man is in his original source. [13] Nevertheless, as man is a metaphysical being, what is known about man is far less than what is not known about him. For Buber, "man is that way by nature; for man by nature is not a finished product like other beings. Hence, Buber writes:

... he is not a determined, unambiguous, final species like the others, he is not a finished form, but something that is only becoming. [14]

The study of man is, therefore, a continuous process. For this reason, the final knowledge of man is only achieved in God. Buber understand this man's self-transcendence from the point of view of his metaphysical tendency to God. Thence, man is defined not merely by distinguishing him from other animals, but rather from the point of his becoming-ness. On this ground Buber furthered thus: In my view, however, man is not 'radically' this or that. It is not radicality that characterizes man as separated by a primal abyss from all that is merely animal, but it is his potentiality.. but he is this potentiality in its factual limitation? The wealth of possibility in existence from which the animals are kept away by their exiguous reality is exhibited in man in a sign that is incomprehensible from the stand point of nature. [15]

\section{The Dynamic Nature of Man}

Man is an animal that has future to shape. He can fashion and re-fashion his situation and environment. Hence, he can influence his environment and can equally be influenced by his environment as well. This is only driving to the fact that man is not a static being. Man is continuously in the process of becoming. It was at this point that Heidegger declared man "a bundle of possibility". [16] There is a chain of possibilities in man. Thus Greece affirms: Man is possibility, he has the power to be. His existence is in his choice of the possibilities which are open to him and since this choice is never final, once and for all, his existence is under determinate but not terminated. [17]

Batista Mondin in agreement with this line of thought, meaningfully and ardently insists that: This bundle of infinite possibilities, which the human person is, is capable of transcending the heights of innovation, plumbing the infinite depths of reality and mastering the tyrannical hold of inclement nature. These are on the positive scale. Here, man could be romantically labelled an angel. [18]

In essence, man is neither this nor that but can be this or that. He is like a log of wood which can be broken into firewood or made into any form of furniture. It can as well be carved into an image of anything you can think of. Man ceaselessly found himself in a condition where both the good and evil intermingle. He is neither good nor evil but can choose to be good or evil. "Man is not good, man is not evil; he is in a pre-eminent sense, good and evil together". [19]

Consequently, it is in this face to face with good and evil simultaneously that man realizes himself. For instance, Adam and Eve realized their nakedness after they had eaten the fruit of the good and evil. It is only in that condition can man make choices. This choice determines the humanness of a man. This is the cause of the discrepancy between animals' domain and that of man. Animals are only one-way traffic as regards their mode of life, but that of man is diversified. Animals have no future to shape. Hence, animal life has become so mechanical. But man has diversified ways of living because of his freedom to choose. Possibly, it is as a result of this that St. Thomas Aquinas maintained that it is in the nature of man to be free. [20] Inferring from the point above, one can then correctly contends that the man's freedom is made possible in the face of choice and decisionmaking to which man is subjected to.

Invariably, the possibilities of which man is a bundle of, endows him with the deliberate intention of self-expression, self-determination and self-shaping, and, therefore, he can consciously fashion and refashion his pattern of life. This endowment characterizes man as an animal that can work home Faber. In this regard, therefore, Byrne \& Maziarz put thus: It is known, of course that sub-human animals can 'use' tools, but only man manifests the capacity to respond to change and control his environment by making tools. [21]

Among all the animals, none is capable of controlling and manipulating its situation and environs as man, neither can any make or use sophisticated tools as man. For this reason, the question of the world always calls to mind the question of man. It is always the world of man in which there is no order without an orderer who is man himself. It is because of this that Macquarie writes:... whenever we talk of the world, we talk at the same time of man, for the expression world implies a human standpoint from which everything is seen as environment. [22]

In the same vein Karl Jaspers opines that: If I oppose myself to the world, it is still only within the world, and through it, that I am what I am. The world I can know is not without this knowing I - any more than I am without the world I need to be I. There is neither an I-less world nor a world-less I. [23]

Little wonder Sartre claims that man ought to affirm himself as a being through whom a world exists. [24] However, unlike Sartre, Buber maintains that the world does not exist through man, rather, that man's existence endows the world with meaning. "Meeting with God... comes to man..., in order that he may confirm that there is meaning in the world". [25]

So, the world does not exist through man but found its meaning through man. Man is a being in the world. In this world, man is not alone.

Man's being is by nature in the world, in a world in which man is not merely surrounded by things which are his 'gear', that is, which he uses and applies... but also by men together with whom he is in the world. [26]

He further explicates that: We are created along with one another and directed to a life with one another. Creatures are placed in my way so that I, their fellow-creature, by means of 
them and with them find the way to God. A God reached by their exclusion would not be the God of all lives in whom all life is fulfilled. [27]

\section{Conclusion}

Man, therefore, does not only find himself in the world, but is also part of this world. Then, any clear study of man must consider man in relation to these other beings together with whom man is in the world. Man is not only a part of the cosmos in which he finds himself, by demarcating himself from every other being but also by entering into relation with them. As a pilgrim of the divine on earth, man should react and interact with his world and fellowmen along with whom he is a fellow traveller. Philosophers like Martin Buber concord with the above point as he insists that: The question, what man is cannot be answered by a consideration of existence or of self-being as such, but only by a consideration of the essential connexion of the human person and his relation with all beings. [27]

Since man is not alone in the world and since man's being is influenced highly and is shaped by his environs, the definition of man cannot do without relation to man's surroundings, for man is the being who is capable of threefold living relation and can raise every form of it to essentially. [27]

Accordingly, therefore, the absolute answer to the question of what man is, is in the Divine. This is true, since man is "a being in whom God loves himself". [27] It is in the living relation with the eternal thou that man comes to the full knowledge of himself. Man as a created being, on the basis of metaphysical principle of finality, is driving on as well as sustained by its metaphysical and meta-psychical desire to see God.

All man's endeavour and possibilities terminate in man's union with God. However, man is better described than defined. Admittedly, therefore, the fundamental fact of human existence is man's relation with man which in turn facilitates his relation with God. Here is embedded the meaning of what man is. However, man exhibits twofold attitudes towards relation. Relationship can either be exploitetive (selfish) or cordial (selfless).

\section{References}

[1] Buber, M. (1947) "Between Man and Man". Great Britain, p. 24.

[2] Aquinas, T. Quoted in Eberl, J. T. (2004) "Aquinas on the Nature of Human Beings", The Review of Metaphysics, Vol. $58(2), 333-363$.

[3] Gratsch, E. T. (1985) "Aquinas' Summa: An Introduction and Interpretation", Alba House, New York.

[4] Plato, (2015) "Great Dialogues of Plato", trans. W. H. D. Rouse, Rebecca Newberger Goldstein, USA.
[5] Aquinas, T. "Summer Theologia" 1a q. 76, a. 3c.

[6] Donceel, J. F. (1967) "Philosophical Anthropology ", New York, p. 455.

[7] Heidegger, M. Quoted in Buber, M. (1947) Between Man and Man, Great Britain.

[8] Onwuatuegwu, I. N. and Emekwulu, V. C. (2020) "The Issue of Freedom and Responsibility in Sartre's Philosophical Propoundment", IAR Journal of Humanities and Social Science, 1 (4) 218-222.

[9] Onwuatuegwu, I. N. (2021) An Attempt at God's Definition: A Philosophic- Metaphysical Rationalization", International Journal of Arts, Humanities and Social Studies, 3 (2), 1-3.

[10] Aquinas, T. Op. cit., 1a q. 44, a, 1c.

[11] Onwuatuegwu, I. N. (2021) "The Intrinsic Metaphysical Tendency of Man in the Psycho- Philosophical Theory of Martin Buber", International Journal of Social Science and Human Research, 4 (3), 501-504.

[12] Scheler, M. Quoted in M. Buber (1947) "Between Man and Man", Great Britain, p. 220.

[13] Onwuatuegwu, I. N. (2010) The Relevance of Martin Buber's Structure of Relationship in Our Present Day Society: An Analytic Approach", Rex Charles and Patrick Publications, Nimo, p. 5.

[14] Buber, M. Op. cit., p. 183.

[15] Buber, M. OP. Cit., p. 102.

[16] Iwuagwu, E. K. (2017) "Martin Heidegger and the Question of Being", Journal of Integrative Humanism (JIH), 8 (1), 2548.

[17] Greece, M. (1957) "Heidegger Martin". London, p. 21.

[18] Mondin, B. (1985) "Philosophical Anthropology: man: an Impossible Project?", Pontificia Universitas Urbaniana.

[19] Buber, M. Op. cit., p. 103.

[20] Eberl, J. T. (2004) "Aquinas on the Nature of Human Beings", Review of Metaphysics, 58 (2): 333-365.

[21] Byrne \& Maziarz (1969) Human Being and Being Human: Man's Philosophy of Man, New York, pp. 134-135.

[22] Macquarie, J. (1972) "Existentialism ", New York, p. 80.

[23] Jaspers, K. (1969) Philosophy, Vol 1, trans. E. B. Ashton, Chicago, p. 100.

[24] https:philosophynow.org/issues/15/A_s...d_Humanism.

[25] Buber, M. (1958) "I and Thou ", trns. Ronald Gregor Smith, Charles Scribner's Sons, New York, p. 115.

[26] Buber, M. (1947) "Between Man and Man", trans. R. G. Smith, Collins Clear-Type Press, Great Britain, p. 205.

[27] Buber, M. Op. cit., p. 73, 219, 166. 